\title{
A MODEL OF CRISES IN EMERGING MARKETS*
}

\begin{abstract}
Michael P. Dooley
This paper presents a perfect foresight model of speculative attacks on emerging markets. Credit constrained governments are assumed to have two objectives: to accumulate liquid assets in order to self-insure against shocks to national consumption and to insure poorly regulated domestic financial markets. This policy regime generates endogenous fiscal deficits defined to include the growth of contingent liabilities. The model sets out a sequence of yield differentials consistent with capital inflows followed by anticipated speculative attacks. The model suggests that a common shock generated capital inflows to emerging markets in Asia and Latin America after 1989.
\end{abstract}

Exchange market and banking crises in Latin America and, more recently, in Asia and Russia have renewed interest in the economics of speculative attacks. Two types of models have dominated formal analysis. First generation models, reviewed in Agenor et al. (1992) interpret speculative attacks as the natural and anticipated demise of an inconsistent policy regime. Proponents of this approach emphasise the conflict between objectives for nominal exchange rate stability and a monetary/fiscal policy that is inconsistent with this objective.

Confidence in these models as complete explanations of speculative attacks has been eroded by the observation that, in many cases, the underlying policy conflict seems to be missing. ${ }^{1}$ The ERM crisis in 1992 and the Mexican crisis of 1994 have been cited as examples of crises not preceded by policy conflicts. Moreover, an important empirical regularity associated with recent crises in emerging markets is that speculative attacks are preceded by very large private capital inflows into the country. This seems to suggest that bullish market sentiment collapsed at the time of the attack.

These observations have inspired models that identify conditions under which a regime is vulnerable to shifts in private expectations. Second generation models, reviewed in Eichengreen et al. (1996), explain speculative attacks in terms of the fundamentals identified in first generation models, but the fundamentals are themselves sensitive to shifts in private expectations about the future. While a shift in market expectations about future policies could

\footnotetext{
* I am grateful to Robert Flood, Dale Henderson and anonymous referees for helpful comments on earlier drafts. Some of the work on this paper was done while the author was employed by the International Finance Division, Board of Governors of the Federal Reserve System. The views in this paper are solely the responsibility of the author and should not be interpreted as reflecting the views of the Board of Governors of the Federal Reserve System or of any other person associated with the Federal Reserve System.

1 See Frankel and Rose (1996) for evidence that fundamental conflicts emphasised in first generation models are not apparent preceding recent crises. Krugman (1996) argues that first generation models are useful in understanding recent crises. He emphasises the fact that a range of policy conflicts that are difficult to measure can trigger an attack. For example, an extended period of high unemployment can conflict with the government's commitment to a fixed exchange rate and the associated constraint on monetary policy. Moreover, he argues that in some models multiple equilibria are ruled out because an attack will occur on the first day it could occur. Kehoe (1996) and Obstfeld (1996) argue that multiple equilibria are possible in a wide variety of theoretical models.
} 
trigger an attack in first generation models, the spirit of the approach would demand that they have a good reason to change their minds in terms of perhaps unobservable fundamentals. ${ }^{2}$

The objective of this paper is to set out a first generation model based on an alternative set of fundamentals. The general structure of the model is drawn from Diaz-Alejandro (1985), Velasco (1987) and Dooley (1994, 1996a). The primary appeal of first generation models is that they relate fundamentals that evolve smoothly to discrete changes in regimes and asset holdings. The mechanism that accomplishes this is an anticipated sequence of yields on real or financial assets that shapes the behaviour of competitive and rational investors. ${ }^{3}$ The model developed in this paper is in this tradition. The policy conflict in the background of our model is between the desire of a creditconstrained government to hold reserve assets as a form of self-insurance and the government's desire to insure financial liabilities of residents. The first objective is met by the accumulation of liquid assets. The second objective generates incentives for investors to acquire the government's assets when yield differentials make this optimal.

These ingredients provide a perfect foresight capital inflow/crisis sequence. The availability of free insurance raises the market yield on a set of liabilities issued by residents for a predictable time period. The yield differential relative to international returns generates a private gross capital inflow (a sale of domestic liabilities to nonresidents) that continues until the day of attack. The gross private capital inflow is necessarily associated with some combination of an increase in the government's international reserve assets, a current account deficit and a gross private capital outflow. An accumulation of international reserves delays the crisis, but when the government's marketable assets are exactly matched by its contingent insurance liabilities, the expected yield on domestic liabilities falls below international rates and investors sell the insured assets to the government, exhausting its assets. The speculative attack is fully anticipated and, at the time of the attack, nothing special happens to the fundamentals or expectations about the fundamentals.

We argue that this is a unifying framework for understanding recent crises in emerging markets. The fall in international interest rates after 1989 generated capital gains on external debt of governments of developing countries. As a result many governments became credible insurers and this initiated capital inflows into developing countries that had little else in common. The coincident inflows were followed by crises, the timing of which was determined by

${ }^{2}$ Garber (1996) points out that first and second generation models are observationally equivalent if expectations for fundamentals change for good reasons not observed by the econometrician.

3 Salant and Henderson (1978) extend Hotelling's (1931) paper on the economics of exhaustible resources to consider a situation in which the government distorts the real return on stocks of gold by fixing its nominal price. The private sector knows that if a speculative attack exhausts the government's gold reserves stock, and ends the price fixing regime, the price of gold will henceforth rise at the real interest rate. This sequence of expected yields implies that the government will hold all stocks prior to the attack and that private investors will buy the entire stock of government holdings in a speculative attack. Krugman (1979) and Flood and Garber (1984) adapted the idea to a fixed exchange rate system.

(C) Royal Economic Society 2000 
country specific factors. The model developed in the next section suggests that crises occur first in countries with poorly-regulated and open financial markets and then in well-regulated and relatively closed economies. Crises might be bunched together in time but this does not reflect contagion but the fact that observed crises generate revisions about the size of credit lines available to governments of emerging markets. Economic reform programmes in developing and formerly planned economies also have generated country specific shocks to governments' assets that may have triggered capital inflow/crisis sequences. These episodes are more difficult to identify empirically and are a topic for further research.

An appealing feature of the model is that an anticipated crisis need not be preceded by an exchange rate-policy conflict or by expectations that a currency peg will be maintained during the capital inflow phase or abandoned as a result of the crisis. It follows that interest differentials across currencies are not always associated with anticipated crises. Moreover, in contrast to existing first generation models, private capital inflows always precede the crisis and are an integral part of a sequence that ends in an anticipated speculative attack against the government's stock of assets.

\section{An Insurance Model}

The essential nature of the capital inflow/attack sequence is captured by the following simple model. We assume there are no unsecured and incentive compatible debt contracts for government borrowing from the private sector. Thus, the government faces a credit ceiling and cannot borrow from the private sector against future tax receipts. It is also assumed that the government can credibly offer marketable assets as collateral against liabilities to private lenders. This collateral consists primarily of international reserve assets and lines of credit from other governments and international organisations. ${ }^{4}$ We assume that there is no market in which the private sector can neutralise the government's decision to accumulate marketable net assets.

In addition to the above assumptions about government finance, assume a small open economy that uses an international money. The economy is in a steady state equilibrium with no growth. Financial intermediation is carried out by commercial banks that are competitive and costless. Banks issue deposits and make loans to residents and nonresidents. Banks also appropriate deposits subject to monitoring by depositors and a regulatory agency. Appropriation is any activity that benefits the intermediary or its principle at the expense of asset values. For example, governments might instruct banks owned

\footnotetext{
4 One interpretation of these assumptions is that international organisations can enforce unsecured contracts but the private sector cannot. For simplicity there is no distinction between domestic and external private debt. If the government could borrow from residents without collateral we would add this credit line to that available from the official sector in order to calculate net assets. In this case private residents would lose in the event of a crisis since their claims on the government will not be honoured. This may explain the severe and lasting depression of asset prices and economic activity following recent crises.
}

(C) Royal Economic Society 2000 
or controlled by the government to lend to firms that do not earn the competitive rate of interest in order to promote exports or employment or subsidise its constituents. More directly, the managers of a bank might book a new loan at more than its market value and invest the difference offshore. The offshore investment is, of course, not recorded on the bank's books or in the balance of payments accounts. Once the funds are offshore, they are beyond the reach of depositors and the regulatory agency.

Resident and nonresident depositors have perfect foresight and can monitor banks' appropriation without cost. Although not necessary for the main results, it is realistic to assume that domestic bank deposits are imperfect substitutes for other assets so that residents' and nonresidents' demand for the stock of deposits is, ${ }^{5}$

$$
D=D\left(R-R^{*}-R P\right), D^{\prime}>0, D^{\prime \prime}<0,
$$

where $R$ is the domestic deposit rate, $R^{*}$ is the international risk-free rate and $R P$ is the additional yield necessary to offset anticipated losses on the marginal deposit net of insurance if a crisis should occur. A crisis is defined as an event in which depositors force the bank to sell its assets and collect deposit insurance from the government. ${ }^{6}$ As long as depositors earn expected yields consistent with (1) there is no incentive for an attack on the government's assets. Depositors will hold insured liabilities and allow the government to hold reserves that earn $R^{*}$.

It is convenient but not necessary to start from a situation in which the government has never had positive net marketable assets and so there has never been credible deposit insurance. We will show that this can only be consistent with an initial risk premium of zero and no appropriation. It is also convenient, but not necessary, to assume that the initial stock of deposits is consistent with an equilibrium in which $R=R^{*}$. The shock to the system at $t_{0}$ is an unexpected increase in the government's net assets, $N_{0} A$.

If banks appropriate all funds generated by selling new deposits the government's implicit liability is equal to the increase in deposits. ${ }^{7}$ The risk premium following a positive shock to the government's net assets at $t_{0}, N A_{0}$, is

$$
\begin{gathered}
R P_{t}=0 \quad \text { if } N A_{t}=N A_{0}-\left(D_{t}-D_{0}\right)>0 \\
R P_{t}=-N A_{t} / D_{t} \quad \text { if } N A_{t} \leqslant 0 .
\end{gathered}
$$

Banks can now offer deposit rates above $R^{*}$ with no change in the default risk

\footnotetext{
${ }^{5}$ We assume that depositors do not participate in the appropriation. In a richer framework the distribution of the rents between depositors and banks, or in a more general case between insured institutions and their creditors, would depend on their relative bargaining powers. If regulators demand that deposits be matched by new loans and that loans be collateralised, owners of collateral would have some market power and would capture some or all the rents. This might account for the boom in property and equity prices often associated with capital inflows.

${ }_{6}$ There is no liquidity problem in that the banks can sell all their assets without depressing their market value.

7 The share of insured deposits that is appropriated is specific to the country and is small in a wellregulated market and large in a poorly-regulated market. The growth rate of deposits that triggers an audit is also specific to each country and is also a function of the supervisory system in place.
}

(C) Royal Economic Society 2000 
premium and can do so as long as $(2 a)$ holds. ${ }^{8}$ We assume that domestic bank regulators cannot directly observe appropriation but can observe deposit growth for every bank. The regulators know that unusual deposit growth for an individual bank might be a signal that appropriation is taking place. They therefore set a ceiling growth rate, $g$, for each bank. If deposits exceed that growth rate the bank is audited and appropriation, if present, is discovered and the bank closed. ${ }^{9}$

The problem for banks is to set the deposit rate $R$ to maximise the expected value of appropriation. In this simple model this is equivalent to setting $R$ in each time period so that deposits grow at the highest rate that does not trigger an audit. If that growth rate is set by the government at $g$ for all banks, (1) can be solved for the sequence of deposit rates that generates the desired growth in deposits.

$$
R_{t}=D^{-1}\left[D_{0}(1+g)^{t}\right]
$$

(where $t$ is the number of periods following the shock).

This strategy is profitable for the banks as long as the premium investors demand on the marginal deposit is less than the share of that deposit appropriated.

We now guess that this process continues until the initial net asset position of the government is exactly offset by new implicit insurance liabilities at time $T$. At time $T$ government liabilities are again just equal to assets. But the speculative attack must occur on day $T$ because the marginal depositor at time $T$ would expect to be almost fully insured. This is true if the expected loss is the probability that the $T$ period depositor would be last in line for insurance if a crisis occurs. Since this probability is very small, the depositor would accept a very small risk premium as set out in (1) and $(2 b)$.

The banks are still able to appropriate the new deposit because deposit growth remains within the limit set by the authorities. So appropriation remains profitable. But now an attack will result in an aggregate loss for existing depositors because the liquidation value of the bank net of insurance is less than the value of deposits. Since this loss is borne by existing depositors competition to avoid certain losses after $T$ will generate an immediate run on the insurance fund at $T$.

Deposit growth would come to an end at $T$ if deposit insurance only applied to deposits issued before $T$ or if the banks raised the deposit rate for all deposits to compensate for expected losses. In either case appropriation

${ }^{8}$ If the insurance is only available on domestic (foreign currency) liabilities an equilibrium covered interest differential will emerge in favour of domestic (foreign currency) liabilities. A fixed exchange rate regime is not crucial for the argument. Under floating exchange rates the nonresident investor plans to liquidate her position at the time of the anticipated attack. It follows that any spot foreign exchange transactions will be offset by a matching forward exchange transaction. Private interest arbitrage will ensure that there is no net change in spot or forward rates.

9 The assumption that the regulator uses this rule of thumb is unrealistic but allows us to model bank behaviour in a simple way. An alternative framework would treat the insurance fund as a common resource and banks would have to find the optimal strategy for appropriating some share of the common fund subject to other banks' behaviour, regulatory constraints and rates of return.

(C) Royal Economic Society 2000 
cannot be profitable because the risk premium associated with a marginal increase in deposits is exactly equal to marginal appropriation.

Because there is no further increase in the government's implicit liabilities, it appears that while the regime is vulnerable an attack would require some further shock. But this is not the case as long as domestic deposits are imperfect substitutes for foreign assets. After $T$, commercial banks' losses will grow faster than the government's ability to insure those losses. Recall that at $T$ the difference between the market value of banks' assets and deposits is equal to the government's net assets. The banks' insured losses are growing at $R_{T}$. But the government's net assets grow at $R^{*}$ which is clearly lower at and after $T$. Competition among depositors to avoid losses will trigger an immediate attack.

Because a crisis will occur at the first transition from positive to negative net assets, an unexpected decline in the market value of assets will also trigger an attack if the decline is large enough to generate net liabilities. In this case existing depositors will lose but will still attack immediately to minimise losses.

Finally, note that the crisis does nothing to resolve the underlying policy conflict. Following the crisis the government will once again attempt to accumulate liquid assets and unexpected capital gains and losses on the government's asset position will eventually generate a new inflow/attack sequence.

\section{Insurance Coverage of Recent Inflow/Attack Sequences}

In this Section we develop an accounting framework to help evaluate the role of insurance in recent crises. Table 1 presents the data to be confronted. The

Table 1

Capital Flows and Liquid Assets for Selected Emerging Markets

\begin{tabular}{|c|c|c|c|c|c|c|}
\hline & Period & $\begin{array}{c}\text { Change in private } \\
\text { liabilities to } \\
\text { nonresidents* }\end{array}$ & $\begin{array}{l}\text { Net private } \\
\text { capital } \\
\text { inflows } \dagger\end{array}$ & $\begin{array}{c}\text { External } \\
\text { debt } 1989 \neq\end{array}$ & $\begin{array}{l}\text { Increase in } \\
\text { official } \\
\text { reserve } \\
\text { assets§ }\end{array}$ & $\begin{array}{c}\text { Rescue } \\
\text { packagell }\end{array}$ \\
\hline China & $1990-98: 4$ & 202.8 & 60.5 & 44.9 & 131.2 & n.a. \\
\hline Brazil & $1990-98: 2$ & 162.3 & 147.9 & 111.3 & 62.1 & 41.5 \\
\hline Argentina & $1990-98: 2$ & 126.1 & 69.4 & 64.7 & 23.3 & n.a. \\
\hline Korea & $1990-97: 2$ & 120.2 & 66.1 & 33.1 & 15.4 & 52.8 \\
\hline Mexico & $1990-94: 1$ & 114.4 & 95.7 & 95.6 & 19.6 & 47.0 \\
\hline Thailand & $1990-96: 2$ & 68.7 & 86.3 & 23.5 & 29.3 & 17.2 \\
\hline Russia & $1994-97: 2$ & 41.9 & -30.5 & 79.0 & 5.3 & 23.0 \\
\hline Indonesia & $1990-97: 3$ & 44.8 & 48.0 & 53.1 & 15.9 & 40.0 \\
\hline Malaysia & $1990-97: 3$ & 42.2 & 40.7 & 18.6 & 17.7 & n.a. \\
\hline India & $1990-98: 4$ & 37.3 & 60.3 & 62.5 & 23.5 & n.a. \\
\hline Turkey & 1990-98:3 & 29.7 & 34.9 & 41.6 & 14.7 & n.a. \\
\hline Chile & 1991-98:3 & 28.3 & 31.4 & 18.2 & 12.0 & n.a. \\
\hline Hungary & 1991-98:4 & 28.0 & 23.1 & 20.6 & 8.0 & n.a. \\
\hline
\end{tabular}

\footnotetext{
* Source: IFS 78 b e d +78 b g d +78 b u d.

$\uparrow$ Source: IFS $78 \mathrm{adzf}-79 \mathrm{dbdzf}$.

+ Source: World Bank, Global Development Report.

$\S$ Source: IFS, 1L.D2F.

II Source: BIS, $69^{\text {th }}, 70^{\text {th }}$ Annual Report.

(C) Royal Economic Society 2000
} 
thirteen emerging markets listed accounted for more than $80 \%$ of all capital inflows to emerging markets from 1990-8. The insurance model developed above suggests that residents respond to credible insurance by selling insured liabilities to nonresidents in order to appropriate some share of the proceeds. The capital inflow episodes are identified as the interval following 1990 during which quarterly data shows continuous increases in governments' holdings of reserve assets. Column 2 of Table 1 presents a measure of cumulative gross private capital inflows into each emerging market during the episode. This measure of gross private capital inflows includes all sales of liabilities to nonresidents by private residents recorded in the balance of payments, including direct investment. An alternative measure of net private capital inflows is shown in column 3. Since we are interested in the stock of liabilities covered by insurance, we would like to know if nonresident investors could offset expected losses by forcing residents to liquidate foreign assets. If this was the case the proper measure of insured inflows is the net capital inflow shown in column 3 .

There is no obvious way to make such a judgement. The Russian private sector, for example, had more than enough foreign assets to repay all the gross foreign liabilities shown in column 2. But the insurance model suggests that private capital flight from the emerging market might be motivated by the desire to avoid contributing to the government's insurance fund. To be conservative in evaluating our approach we will consider the larger of the two measures of capital inflows for each country as the stock of liabilities to be covered by government insurance. The question, then, is can changes in the availability of insurance explain the timing and magnitude of these inflows?

\subsection{Sources of Marketable Assets}

Three 'insurance fundamentals' must be present in order to generate a capital inflow/crisis sequence. The first is that a credit constrained government must have positive net marketable assets. Recall that marketable assets are defined to include some contingent assets and liabilities but not the present value of future tax receipts. Second, the government's commitment to exhaust these net reserves to pay off implicit or explicit insurance contracts must be credible. That is, it must be consistent with the government's incentives and ability to mobilise and exhaust a well defined set of assets after the attack begins. Third, private investors must have access to transactions that produce insured losses.

All three factors must be present to trigger a capital inflow and subsequent attack. One or two of these fundamentals are found in most countries most of the time. But as long as one ingredient is missing there will be no capital inflow and no crisis. Crisis episodes are associated with the relaxation of a binding constraint. It follows that there is no simple temporal ordering of changes in insurance fundamentals and crises. It also follows that an important change in the international environment might relax or reimpose a binding constraint in many countries at the same time.

For middle income developing countries with substantial stocks of external debt the missing fundamental from 1982 to 1989 was a stock of marketable 
assets to support a credible insurance commitment. For this group of countries an important source of changes in the value of governments' net marketable assets has been changes in the market value of governments' external debt caused by changes in international interest rates.

The capital gain on external debt outstanding after 1990 was the product of outstanding debt and the change in the relevant interest rate on that debt. Because the currency denomination of the Latin American and Asian debt was quite different in 1990 we construct a weighted average international interest rate for each debt stock (Fig. 1). The sensitivity of the market value of Latin debt to changes in international interest rates is clear because it traded at substantial discounts before the drop in interest rates. As shown in Fig.1, the price of Latin debt rises from about thirty cents to near par as interest rates declined after $1990 .^{10}$ There is no similar change in the market value of Asian debt because its market price was near par in 1990 .

Our interpretation of this data is that Latin governments could not have had net assets to cover new insurance as long as existing government liabilities sold for substantially below par. The fall in international interest rates eliminated the claims of existing creditors in excess of governments' assets in 1990. The capital gain was about one-half of the initial stock of floating rate external debt shown in column four of Table 1.

From this point forward capital gains on debt and other asset accumulation

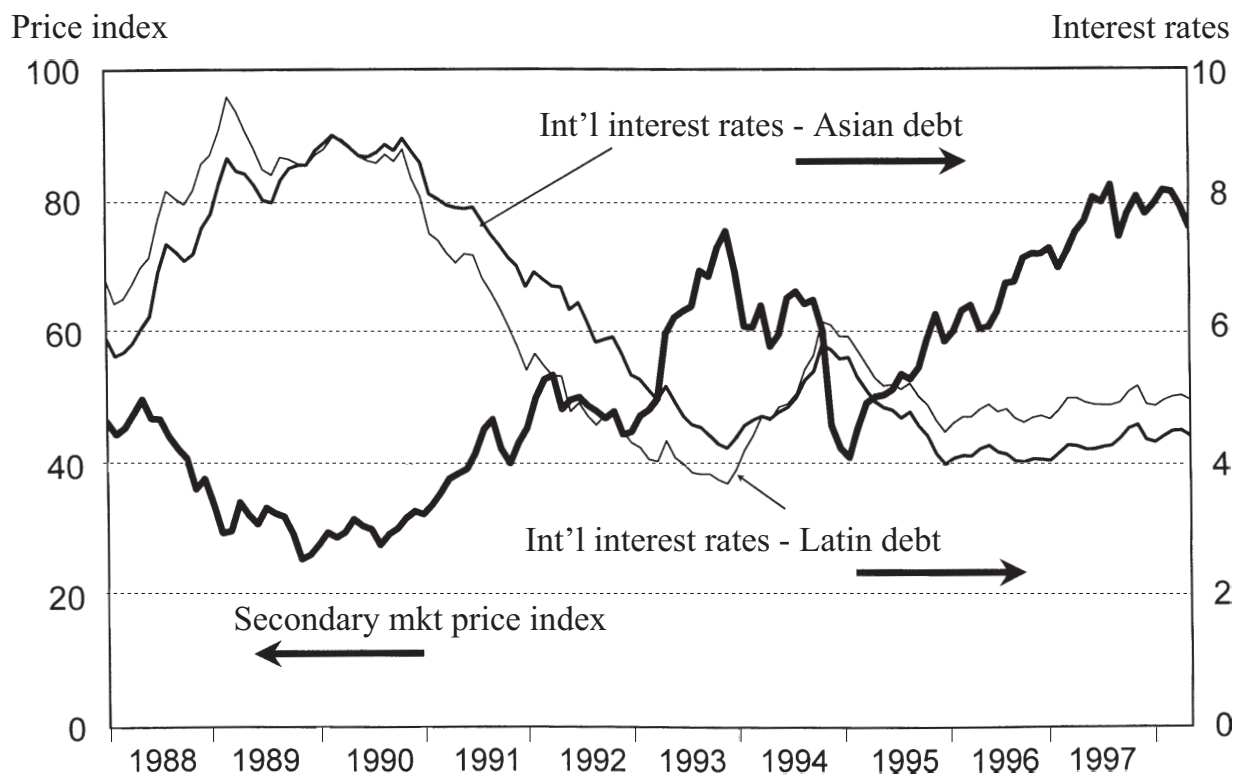

Fig. 1. Secondary Market Prices, Latin Debt and International Interest Rates

\footnotetext{
10 See Dooley et al. (1996) for a model of sovereign debt prices and the effect of changes in interest rates and other factors.
}

(C) Royal Economic Society 2000 
provided a credible insurance pool. A similar capital gain for Asian governments created an immediate insurance pool. While only suggestive, these data are consistent with the view that, except in the transition economies, capital gains on debt could have triggered capital inflows into emerging markets after 1990.

As the fall in international interest rates cut the market value of emerging market governments' liabilities, economic reform programmes provided substantial new assets. Column 6 shows the size of credit lines offered by creditor governments and international organisations for the six countries that have had crises to date. The determinants of these lines of credit vary from country to country. In general creditor governments and international organisations have supported economic liberalisation in developing countries and transition economies. This is the second important exogenous source of insurance for these countries.

Liberalisation programmes tended to relax all three constraints on capital inflows. First, they made domestic liabilities available to foreign investors and second, they made the existing regulatory framework less effective. Our approach emphasises the third effect. Creditor governments and international organisations have provided generous lines of credit to support reform programmes.

The decline in international interest rates and the expansion of lines of credit associated with economic reform programmes initiated the capital inflow sequence. The insurance model suggests that the substantial accumulations of international reserve assets sustained and magnified the inflow. Column 5 of Table 1 shows the changes in reserve stocks during the inflow episodes. Governments of these countries did not accumulate reserves with the intention of providing insurance. In most cases reserve accumulation was a byproduct of sterilised intervention designed to preserve some monetary independence along with managed exchange rates. In Section 3.4 below we develop the point that exchange rate regimes that generate large accumulations of reserves are particularly vulnerable to insurance crises.

We are now ready to answer the key question. Is it plausible that private investors could have anticipated the observed crises? If we consider the largest measure of capital inflows for the six countries that have had crises, rescue packages and reserves covered on average $64 \%$ of the stock of foreign liabilities at the time of the crises. It follows that, on average, investors had to expect to recover only $36 \%$ of the value of their investments to break even. For five of the six countries the range of coverage is quite narrow, from $54 \%$ for Thailand to $68 \%$ for Mexico. Indonesia is an outlier with coverage of $116 \%$. If we consider the smaller measure of net capital inflows, coverage averages $94 \%$. Depending on the measure of liabilities at risk, insurance was either a very important or decisive factor ex post in allowing private investors to liquidate their claims on emerging markets. It seems quite reasonable to assume that expected insurance was an important factor in generating the capital inflows in the first place.

Two reasonable refinements of these calculations would tend to increase the

(C) Royal Economic Society 2000 
estimate of insurance coverage. Some share of direct investment might be excluded on the grounds that these foreign liabilities are hedged by real assets in the debtor country. Moreover, it might be correct to add some part of the capital gain on debt in 1990 to the insurance pool. One refinement that would tend to reduce the estimate of coverage would be to reduce the size of expected rescue packages to the lines of credit that have actually been drawn in the six cases for which we have data. On balance, the simple quantitative framework presented here may provide a reasonable assessment of the quantitative importance of insurance for recent inflow/crisis sequences.

\section{Related Empirical Regularities}

In this section we turn to other empirical regularities associated with recent crises that we believe are also consistent with the insurance model. These include the bunching of crises-usually interpreted as a result of contagion, the composition of capital inflows-often interpreted as a causal factor in crises, the relationship between banking crises and exchange market crises and, finally, the relationship between crises and the exchange rate regime.

\subsection{Contagion}

Crises are much too bunched over time to be plausibly considered independent events. This seems to favour explanations of crises that are based on changes in private expectations, clearly a problem for any perfect foresight model. But the insurance model provides a plausible alternative explanation for contagion. Although a capital inflow/crisis sequence is likely to begin at about the same time for many indebted developing countries following a decline in international interest rates, the duration of the inflow and the timing of the expected crisis can vary widely. In fact, a crisis might never occur if the government reacts properly. The duration of the capital inflow will depend on the rate at which banks, households and firms can sell insured liabilities and on the profitability of appropriation. Note that in our model the premium demanded by depositors is increasing in both deposits and the expected loss net of insurance. Thus, if the share of each deposit appropriated is low because of regulatory constraints, appropriation may become unprofitable before the government's net assets are exhausted. ${ }^{11}$ The important implication is that crises will be spread over time and move from poorly to well-regulated financial systems. ${ }^{12}$

A common negative shock to governments' net assets could truncate this

11 An important difference between emerging markets and industrial countries is that the governments in industrial countries constrain domestic intermediaries before the government's net worth is exhausted. Thus, in the US savings and loan crisis there was no run on the government's reserves. Instead a binding constraint was established by reregulating the financial system. The resulting loss to the government was substantial but well within its ability to provide credible insurance.

12 See Chinn et al. (1999) for evidence that corruption and the duration of capital inflow episodes are inversely related.

(C) Royal Economic Society 2000 
process and generate a number of crises at the same time. Thus, a change in a common fundamental might account for a bunching of crises. Contagion need not be related to changes in private expectations.

As shown in Fig. 1, international interest rates did rise just before the Mexican crisis in 1994 and this common shock to the market value of debtor governments' liabilities may explain the so-called tequila effect. Crises might also be bunched in time because of revisions in expected values of official lines of credit. When an attack occurs, investors receive new information about the size and likely distribution of official credits available to cover insurance commitments. If the expected overall size of official lending is revised downward this can generate coincident runs in many countries. Following the crisis in Mexico and Russia, for example, there were considerable differences of opinion concerning the willingness and ability of creditor governments and international organisations to support additional loan programmes in the face of political opposition. This may have reduced the expected value of official loans to other countries, perhaps to levels that made immediate attacks optimal. Even if the expected pool of loans is unchanged, the observation of loans to an individual country provides additional information about the expected distribution of loans over countries. On average expectations for half of the countries will be revised downward and some of these might be pushed over the attack threshold.

\subsection{Composition of Capital Inflows}

A richer model of regulatory behaviour would recognise that as the government learns of appropriation techniques it would adapt its regulatory machinery. This game between the government and the private sector might account for the very different structures of capital inflows across countries. If a government focuses on one type of transaction, the private sector will seek alternative and perhaps entirely new patterns of financial intermediation that make appropriation profitable. The important implication is that capital inflows initiated by a common shock to governments' assets will take many different forms.

Commercial bank deposits at 'large' banks are obvious candidates for insurance since a failure of such an institution threatens the payments mechanism. In emerging markets free deposit insurance extended to banks in newly liberalised financial markets has long been cited as a source of instability in financial markets (McKinnon and Mathieson, 1981; Hanson and de Melo, 1983; Diaz-Alejandro, 1985; Corbo et al., 1986; Baliño, 1991; McKinnon, 1991; Velasco, 1991). Akerlof and Romer (1993) and Kane (1995) argue that a deadly brew of insurance, undercapitalised banks, unrestricted competition for deposits and poor prudential regulation has induced banks to reach for risk and generated losses for governments.

The distinguishing feature of recent private capital inflows to developing countries is that they comprise a wide range of instruments in addition to bank deposits. These include equities, direct investments, corporate bonds, and 
government securities (Calvo et al., 1993; Claessens and Gooptu, 1993). It is not obvious that the government of the borrowing country has provided a guarantee for all these liabilities.

But even the liabilities of domestic nonfinancial corporations might carry a strong government backup. Nonresident creditors can liquidate these investments without loss if firms can be expected to ask for and receive credit from the domestic banks. To refuse to do so would depress the market value of the banks' existing claims on the domestic firms and call into question the solvency of the domestic banking system. Groups of financial and nonfinancial firms with cross holdings of ownership are common in emerging markets and this blurs the distinction among their liabilities.

The argument is close to the spirit of that offered by Diaz-Alejandro (1985). Although he emphasised the role of deposit insurance in generating crises in the Southern Cone, he made the much more general point that banks' customers are also implicitly guaranteed. 'Southern Cone domestic financial systems of the late 1970 s and early 1980 s ended up with a pessimum "middle way": de facto public guarantees to depositors, lenders and borrowers, and no effective supervision and control (until it was too late) of the practices of financial intermediaries ... as illustrated in the recent Chilean experience, foreign financial agents will not accept a separation of private and public debts when a crisis arrives' (pp. 17-8).

The insurance model also suggests that the composition of inflows should also reflect private creditors' expectations concerning the preferences for insurers after the crisis is under way. Creditors that are well organised and can block restructuring agreements are typically bought out on favourable terms. International banks for example might replace less powerful creditors as a crisis approaches.

\subsection{Banking and Exchange Market Crises}

The relationship between moral hazard and crises has been emphasised in several models of recent crises in emerging markets. McKinnon and Pill (1996, 1998) and Krugman (1998) argue that recent crises in Asia reflect overborrowing or excessive risk taking encouraged by government insurance. Sachs et al. (1996) provide a clear analysis of how domestic financial liberalisation and weak regulatory systems have generated lending booms in emerging markets. 'Financial liberalization typically is accompanied by aggressive behavior on the part of banks. In order to raise deposits, banks increase interest rates and fund more risky projects. Given the existence of deposit insurance (implicit or explicit) depositors find it profitable to move to these banks. Although the purpose of prudential regulation is to impede this tendency, during the early years of liberalization the capacity for oversight is usually poor. Consequently when significant capital inflows take place in early stages of financial liberalization, lending booms that follow are likely to be associated with an increase in the riskiness and vulnerability of bank portfolios ... The weaknesses of the banking system do not surface until capital inflows reverse' (p. 191).

(C) Royal Economic Society 2000 
The empirical association between banking and currency crises is well established. Gavin and Hausmann (1995) document the relationship between lending booms and financial crises in Latin America. Kaminsky and Reinhart (1996) show, in a sample of 76 balance of payments crises and 26 banking crises in 20 developing countries from 1970 to 1995, that about one-quarter of the banking crises occur within one year of a balance of payments crisis. Their interpretation of the evidence is that balance of payments crises were unrelated to banking crises during the 1970s when financial markets within these countries were highly regulated. Following liberalisation of domestic financial markets in the 1980s, banking and balance of payments crises were closely linked and banking crises preceded balance of payments crises.

Goldfajn and Valdes (1997) examine four recent examples of banking/ balance of payments crises in Finland, Mexico, Sweden and Chile. In each case capital inflows preceded the crises by three to six years and lending booms occurred in domestic banking markets over the same intervals. The crises were followed, except in the case of Sweden, by substantial capital outflows and in all cases by a sharp reduction in bank credit. Their model suggests that intermediation involving maturity transformation is likely to increase capital inflows relative to equilibria in which there is no intermediation but at the cost of increasing the probability of a run on the banking system. Since the run on the banking system depletes reserves, it also increases the chances that a fixed exchange rate regime is abandoned.

This literature has clarified two important points. First, the government's net reserves support two policy regimes: the banking/financial system and the exchange rate regime. An attack on either regime that exhausts reserves will necessarily have important implications for the other regime. This will make identification of the causes of a crisis difficult. ${ }^{13}$ Second, rapid growth in the stock of bank credit may be an early warning that potential losses in the financial system and the associated contingent government insurance liability are approaching a crisis level.

The model proposed in this paper carries the argument a step further. We do not argue that capital inflows, and associated growth in credit, increase the vulnerability of the regime to shifts in private expectations or that liberalisation per se is likely to trigger a crisis. Dornbusch (1997) sets out this view clearly: '... a political reversal could break a pattern of continuity and credibility and lead to a sell off; a bout of easy money would hasten a crisis, a fragile banking system with currency exposure would magnify the collapse, and a liquid debt structure would accelerate and magnify the collapse. Financial considerations are all important in interpreting specific events, but must not be misconstrued as the primary or sole source of a collapse' (pp. 383-4). In the model developed above financial considerations are the primary and sole source of an anticipated collapse.

13 The two objective/one policy tool problem is well known. Wigmore (1987), for example, argues that the choice of the new Federal Reserve system to protect its gold reserves in order to maintain the fixed exchange rate forced them to accept the bank failures that may have triggered the 1930s depression. For a discussion of the conflict in the context of currency boards see Caprio et al. (1996).

(C) Royal Economic Society 2000 


\subsection{Insurance Crises and the Exchange Rate Regime}

A fixed exchange rate is a helpful but not a necessary condition for an insurance attack. Fixed exchange rates are helpful because they give residents an easy way to generate insured losses. For example, a bank can offer dollardenominated deposits at above market rates and make dollar-denominated loans at even higher rates. ${ }^{14}$ If the speculative attack triggers a devaluation, banks and debtors have a plausible story as to why default is unavoidable and the government should step in and insure the financial system. Moreover, sterilised intervention designed to defend the exchange regime generates the endogenous growth in liquid reserve assets that sustains an inflow/crisis sequence.

However, an exchange rate devaluation is not a necessary part of a capital inflow/crisis sequence. Reserves in our model are exhausted because the government has a strong incentive to act as a lender of last resort. The government's incentives to maintain a fixed exchange rate regime once an attack is under way are much less obvious. If reserves are exhausted to support the financial system, even a tiny negative shock might then force the government to devalue. But the initial shock might be positive and there need be no change at all in the exchange rate regime following the attack.

This may explain the fact that returns on domestic currency denominated positions did not indicate that investors anticipated a devaluation prior to recent attacks in Mexico and Thailand. As emphasised by Sachs et al. (1996) the failure of interest differentials across currencies preceding recent crises to compensate investors for anticipated devaluation is an important weakness of first generation models that link devaluation and fundamentals. This seems to be a very general problem in that Kaminsky et al. (1997) place interest differentials near the bottom of sixteen indicators of crises. Our interpretation of this evidence is that changes in exchange rate regimes may not have been associated with anticipated insurance attacks.

\section{Capital Controls and Debt Management}

Credit constrained governments have good reasons to acquire liquid assets and to act as lenders of last resort. Our analysis suggests, however, that the benefits of these activities should be compared to the expected costs associated with crises. If prudential regulation takes time to put in place it might be optimal to delay or reverse liberalisation of international capital flows. Effective regulation of capital inflows might starve an insurance crisis of the fuel that sustains it. In Dooley (1996b) it is argued that a Tobin, or transactions, tax on capital flows is unlikely to be welfare improving because holding periods have not been convincingly related to undesirable speculative behaviour. But the insurance model developed in this paper does provide a clear rationale for an entry tax on capital inflows. The key is that the insurance model provides a

\footnotetext{
14 A clear description of this technique for exploiting insurance is presented in Akerlof and Romer (1993).
}

(C) Royal Economic Society 2000 
good reason to believe that anticipated holding periods of investors who hold insured assets are different, and probably shorter, as compared to investors who do not rely on insurance. The capital inflow/attack sequence has an expected duration. If regulation is weak, the duration is short and a transactions tax would probably fall disproportionately on this type of capital flow. The right transactions tax would eliminate the incentive to hold insured assets but interfere less with the decisions of those who decide to make uninsured investments.

Governments that cannot effectively regulate their financial systems, and are unable or unwilling to control capital flows, can avoid crises by minimising exploitable asset positions. Dooley (1999) argues that debt management policy for such governments should focus on debt and asset structures that minimise the probability of a crisis and the real costs of crises that do occur. A straightforward implication of this analysis is that governments of developing countries should quickly liquidate assets by retiring debt or by transferring assets to the private sector. Such governments should also avoid exchange rate regimes that generate large stocks of reserve assets.

\section{Conclusions}

Second generation models of exchange market and banking crises are motivated in part by the fact that existing perfect foresight models are inconsistent with several important features of recent crises in emerging markets. But second generation models are also problematic. They are driven by unexplained shifts in investors' expectations and are therefore difficult to test. In this paper an alternative first generation insurance model is developed that is consistent with important features of recent crises. The model provides plausible explanations for the timing and size of private capital inflows to emerging markets in recent years, the duration of inflows and the apparent contagion of crises, the composition of capital inflows, the relationship between banking and currency crises, and the role of fixed exchange rates in crises.

The model has important policy implications. International organisations that supply credit to countries in crisis should consider a different kind of conditionality than is usually required for lending. Existing first generation models focus on fiscal and trade deficits as the fundamental causes of crises. It is not surprising, therefore, that conditionality also has focused on reductions in fiscal deficits and exchange rate adjustments. But these policy initiatives will do little or nothing to head off an insurance crisis. As more countries satisfy the three fundamentals for an insurance crisis, a stable international monetary system will require more careful attention to distortions inherent in insured domestic financial systems.

The implications of the model for early warning systems are straightforward. Rapid growth in any type of domestic credit creates a presumption that a binding constraint on an insurance attack may have been relaxed. If the credit boom is fed by capital inflows, this is an additional warning that trouble may 
be brewing. The constraints themselves are easily evaluated. Does the government have net assets including lines of credit? Will the government exhaust those assets to honour its explicit and implicit liabilities? Is there a vehicle for residents to issue insured liabilities that are not subject to prudential regulation? An affirmative answer to all three questions suggests that the regime may be headed for a crash.

\section{University of California, Santa Cruz}

Date of receipt of first submission: November 1997

Date of receipt of final typescript: June 1999

\section{References}

Agénor, P. Bhandari, J. and Flood, R. (1992). 'Speculative attacks and models of balance of payments crises,' IMF Staff Papers, vol. 39, pp. 357-94.

Akerlof, G. and Romer, P. (1993). 'Looting: the economic underworld of bankruptcy for profit,' Brookings Papers on Economic Activity, vol. 2, pp. 1-60 and 70-4.

Baliño, T. (1991). 'The Argentine banking crisis of 1980,' in Banking Crisis: Cases and Issues (V. Sundararajan and T. Baliño, eds.), Washington: International Monetary Fund, pp. 58-121.

Calvo, G., Leiderman, L. and Reinhart C. (1993). 'Capital inflows to Latin America: the role of external factors,' IMF Staff Papers, vol. 40, pp. 108-51.

Caprio, G., Dooley, M., Leipziger, D. and Walsh, C. (1996). 'The lender of last resort function under a currency board: the case of Argentina,' Open Economies Review, vol. 7, pp. 625-50.

Chinn, M., Dooley, M. and Shrestha, S. (1999). 'Latin America and East Asia in the context of an insurance model of currency crises,' Journal of International Money and Finance, forthcoming.

Claessens, S. and Gooptu, S. (1993). World Bank Discussion Papers, No. 228, December.

Corbo, V., de Melo, J. and Tybout, J. (1986). 'What went wrong with the recent reforms in the Southern Cone,' Economic Development and Cultural Change, vol. 34 (April), pp. 607-40.

Diaz-Alejandro, C. (1985). 'Good-bye financial repression, hello financial crash,' Journal of Development Economics, vol. 19 (September-October), pp. 1-24.

Dooley, M. (1994). 'Are recent capital inflows to developing countries a vote for or against economic policy reforms?' Working Paper no. 295, Department of Economics, University of California, Santa Cruz.

Dooley, M. (1996a). 'Capital controls and emerging markets,' International Journal of Finance and Economics, vol.1, pp. 197-205.

Dooley, M. (1996b). 'The Tobin tax: good theory, weak evidence, questionable policy,' in (M. ul Haq, I. Kaul and I. Grunberg, eds.), The Tobin Tax: Coping with Financial Volatility, New York, NY: Oxford University Press, pp. 83-108.

Dooley, M. (1999). 'Governments' debt and asset management and financial crises: sellers beware,' in (M. Cassard and D. Folkerts-Landau, eds.), Risk Management for Sovereign Countries, Washington, D.C.: International Monetary Fund, forthcoming.

Dooley, M., Fernandez-Arias, E. and Kletzer, K. (1996). 'Is the debt crisis history? Recent capital inflows to developing countries,' World Bank Economic Review, vol. 10, no. 1, pp. 27-50.

Dornbusch, R. (1997). 'Brazil's incomplete stabilization and reform,' Brookings Papers on Economic Activity, vol. 1, pp. 367-404.

Eichengreen, B., Rose, A. and Wyplosz, C. (1996). 'Speculative attacks: fundamentals and self-fulfilling prophecies,' NBER Working Paper 5789.

Flood, R. and Garber. P. (1984). 'Collapsing exchange rate regimes: some linear examples,' Journal of International Economics, vol. 17, pp. 1-13.

Frankel, J. and Rose, A. (1996). 'Currency crashes in emerging markets: an empirical treatment,' International Finance Discussion Paper No. 544, Board of Governors of the Federal Reserve System, (January).

Garber, P. (1996). 'Discussion,' NBER Macroeconomics Annual, vol.11, pp. 403-6.

Gavin, M. and Hausmann, R. (1995). 'The roots of banking crises: the macroeconomic context,' Interamerican Development Bank, unpublished.

Goldfajn, L. and Valdes, R. (1997). 'Capital flows and the twin crises: the role of liquidity,' IMF Working Paper no. 97-87.

Hanson, J. and de Melo, J. (1983). 'The Uruguayan experience with liberalization and stabilization,'

(C) Royal Economic Society 2000 
Journal of Inter-American and World Affairs, vol. 25, pp. 477-508.

Hotelling, H. (1931). 'The economics of exhaustible resources,' Journal of Political Economy, vol. 39, pp. 137-75.

International Financial Review, various issues.

International Monetary Fund, International Financial Statistics, various issues.

Kaminsky, G., Lizondo, S. and Reinhart, C. (1997). 'Leading indicators of currency crises,' IMF Working Paper No.97-79.

Kaminsky, G. and Reinhart, C. (1996). 'The twin crises: the causes of banking and balance-of-payments problems,' International Finance Discussion Paper No. 544, Board of Governors of the Federal Reserve, (March).

Kane, E. (1995). The Gathering Crisis in Federal Deposit Insurance, Cambridge: The MIT Press.

Kehoe, T. (1996). 'Comment,' NBER Macroeconomics Annual, vol. 11, pp. 378-92.

Krugman, P. (1979). 'A model of balance-of-payments crises, Journal of Money, Credit, and Banking, vol. 11, no. 3, pp. 311-25.

Krugman, P. (1996). 'Are currency crises self-fulfilling?' NBER Macroeconomics Annual, vol. 11, pp. $345-78$.

Krugman, P. (1998). 'Bubble, boom, crash: theoretical notes on Asia's crisis,' MIT, unpublished.

McKinnon, R. (1991). The Order of Economic Liberalization: Financial Control in the Transition to a Market Economy. Baltimore: Johns Hopkins University Press.

McKinnon, R. and Mathieson, D. (1981). 'How to manage a repressed economy,' Princeton Essays in International Finance. No. 145 (December).

McKinnon, R. and Pill, H. (1996). 'Credible liberalizations and international capital flows: the overborrowing syndrome,' in (T. Ito and A. Krueger, eds.), Financial Deregulation and Integration in East Asia, Chicago IL: Chicago University Press, pp. 7-42.

McKinnon, R. (1998). 'The overborrowing syndrome: are east Asian economies different?' in (R. Glick, ed.), Managing Exchange Rates and Capital Flows: Lessons from the Pacific Rim,' New York NY: Cambridge University Press, forthcoming.

Obstfeld, M. (1996). 'Comment,' NBER Macroeconomics Annual, vol. 11, pp. 393-403.

Sachs, J., Tornell A. and Velasco, A. (1996). 'Financial crises in emerging markets: the lessons from 1995,' Brookings Papers on Economic Activity, no. 16, pp. 147-215.

Salant, S. and Henderson, D. (1978). 'Market anticipation of government policy and the price of gold,' Journal of Political Economy, vol. 86, pp. 627-48.

Velasco, A. (1987). 'Financial crises and balance of payments crises: a simple model of the Southern Cone experience,' Journal of Development Economics, vol. 27, pp. 263-83.

Velasco, A. (1991). 'Liberalization, crisis, intervention: the Chilean financial system, 1975-85,' in (V. Sundararajan and T. Baliño, eds.), Banking Crises: Cases and Issues, Washington: International Monetary Fund, pp. 113-74.

Wigmore, B, (1987). 'Was the bank holiday of 1933 caused by a run on the dollar?' Journal of Economic History, vol. 47 , no. 3 , pp. 739-55. 